\title{
PEMANFAATAN KULIT DAGING BUAH KOPI FERMENTASI MOL (MIKROORGANISME LOKAL) SEBAGAI RANSUM DALAM BENTUK PELET TERHADAP PERFORMANS KELINCI PERANAKAN REX JANTAN LEPAS SAPIH
}

\author{
(Utilization of Pod Coffee Fermented by LMO (Local Micro-Organism) in Pellet Diet on \\ Performances of Crossbred Weaning Male Rex Rabbits
}

\author{
Muhammad Zainul Ihsan ${ }^{1}$, Tri Hesti Wahyuni ${ }^{2}$ dan Usman Budi ${ }^{2}$ \\ 1. Mahasiswa Program Studi Peternakan Fakultas Pertanian Universitas SumateraUtara \\ 2. Staf Pengajar Program Studi Peternakan Fakultas Pertanian Universitas Sumatera Utara
}

\begin{abstract}
The objective of this research was utilization of pod coffee fermented by (LMO) Local Micro-organism in pellet diet on performances of crossbred weaning male rex rabbits. This research was conducted Laboratorium Biologi Ternak at Jl. Dr. Ahmad Sofyan, Faculty of Agriculture, University of Sumatra Utara on to 10 months. The research used completely randomized design (CRD) with 4 treatments and 5 replications. This research used 20 weaning male rex rabbits with initial body weight $913.05 \pm 60.49 \mathrm{~g}$. The treatment were diet consists of $P 0=30 \%$ pod coffee without fermented, $P 1=10 \%$ pod coffee fermented, $P 2=20 \%$ pod coffee fermented, $P 3=30 \%$ pod coffee fermented. The result of this research indicates that the average of feed intake for treatments $P 0, P 1, P 2, P 3(\mathrm{~g} /$ head/day) were $81.59,78.86,82.70$ and 84.23 , respectively, while the average daily gain $(A D G)(\mathrm{g} /$ head/day) were $38.25,38.10,39.61$ and 40.75 , respectively, and feed convertion (FCR) were 2.13, 2.07, 2.09 and 2.07, respectively. The results statistical analysis indicated that the utilizing of pod coffee fermented in diet gaves not significantly different $(P \searrow 0,05)$ on performances of crossbred weaning male rex rabbits. The conclusion of this research that pod coffee fermented can be use for crossbred weaning male rex rabbits feed until level $30 \%$.
\end{abstract}

Keywords : Pod coffee, fermentation, rations of pellet diet, performance, weaning male rex rabbit.

\begin{abstract}
ABSTRAK
Penelitian bertujuan untuk melihat pengaruh dari pemanfaatan kulit daging buah kopi fermentasi mikroorganisme lokal (MOL) sebagai ransum dalam bentuk pelet terhadap performans kelinci peranakan rex jantan lepas sapih. Penelitian ini dilaksanakan di Laboratorium Biologi Ternak Jl. Dr. Ahmad Sofyan Fakultas Pertanian Universitas Sumatera Utara pada selama 10 minggu. Rancangan yang digunakan dalam penelitian ini adalah rancangan acak lengkap (RAL) dengan 4 perlakuan dan 5 ulangan. Penelitian ini menggunakan 20 ekor kelinci peranakan rex jantan lepas sapih dengan bobot awal rata-rata 913,05 $\pm 60,49$ g. Perlakuan terdiri atas $\mathrm{P} 0=30 \%$ kulit daging buah kopi tanpa fermentasi, $\mathrm{P} 1=10 \%$ kulit daging buah kopifermentasi, $\mathrm{P} 2=20 \% \mathrm{kulit}$ daging buah kopi fermentasi, P3= 30\% kulit daging buah kopi fermentasi. Hasil penelitian menunjukan rataan konsumsi dengan beberapa perlakuan (P0, P1, P2, P3) yaitu 81,59, 78,86, 82,70 dan 84,23 (g/ekor/hari), kemudian pertambahan bobot badan (PBB) secara berturut-turut 38,25, 38,10, 39,61 dan 40,75 (g/ekor/hari) dan konversi ransum secara berturut-turut 2,13, 2,07, 2,09 dan 2,07. Hasil analisa keragaman menunjukan bahwa pemanfaatan kulit daging buah kopi fermentasi dalam bentuk ransum pelet memberikan pengaruh yang tidah berbeda nyata $(\mathrm{P} \searrow 0,05)$ terhadap peformans kelinci peranakan rex jantan lepas sapih. Kesimpulan dari penelitian ini bahwa kulit daging buah kopi fermentasi dapat dimanfaatkan sebagai bahan pakan kelinci peranakanrex jantan lepas sapih sampai level $30 \%$.
\end{abstract}

Kata kunci: Kulit daging buah kopi, fermentasi, ransum pelet, peformans, kelinci rex jantan. 


\section{PENDAHULUAN}

Usaha peternakan kelinci di Indonesia belum dapat berkembang dengan cepat dibandingkan peternakan unggas atau ruminansia selain itu, konsumsi masyarakat akan daging kelinci masih tergolong rendah. Hal ini terjadi karena kurangnya informasi di masyarakat bahwa daging kelinci memiliki kualitas yang lebih baik dibanding daging unggas atau ternak lain.

Kelinci sebagai salah satu komoditas ternak yang mudah berkembang biak, tidak banyak membutuhkan modal, lahan dan kandang yang luas serta sebagai hewan penghasil daging, dan dapat dijadikan hewan kesayangan sehingga kelinci perlu dikembangkan dalam skala besar seperti halnya ternak besar yaitu sapi dan domba/kambing. Ternak kelinci menghasilkan daging berprotein tinggi dan sedikit berlemak sehingga daging kelinci aman dari resiko kolestrol.

Pakan merupakan salah satu faktor yang sangat penting bagi kelangsungan jalannya peternakan, mengingat bahwa pakan merupakan biaya terbesar yang dikeluarkan oleh usaha peternakan. Pada pola pemeliharaan intensif, biaya produksi ternak terbesar berasal dari pakan yaitu sebesar 60-70\%. Kemajuan dan perkembangan ilmu dibidang peternakan membuka wawasan untuk memanfaatkan hasil samping limbah dan perkebunan menjadi pakan ternak yang bermutu tinggi serta ekonomis dan tidak bersifat kompetitif dengan bahan makanan untuk manusia, akan tetapi saat ini pakan sangat sulit untuk diperoleh dalam jumlah yang banyak (Anggorodi, 1990). Untuk itu perlu dilakukan alternatif pemanfaatan limbah pertanian, salah satunya kulit daging buah kopi sebagai pakan ternak.

Dalam pengolahan kopi segar akan dihasilkan 45\% kulit kopi, 10\% lender, 5\% kulit ari dan $40 \%$ biji kopi. Di provinsi Sumatera Utara, khususnya daerah dataran tinggi banyak dijumpai perkebunan, salah satunya yaitu perkebunan kopi. Menurut data Dinas Pertanian Bidang Perkebunan Kabupaten Karo (2008), menyatakan produksi buah kopi di Kabupaten Karo mencapai 7.297,8 ton, berdasarkan data diatas dapat diperkirakan menghasilkan kulit daging buah kopi sebesar 3.284 ton setiap tahunnya. Jika tidak dimanfaatkan akan menimbulkan pencemaran. Sementara ini pemanfaatnya belum optimal dan terbatas untuk pakan ternak, karena mempunyai kendala kandungan serat kasar yang tinggi $(33,14 \%)$ dan protein kasar yang rendah $(8,8 \%)$. Untuk menanggulangi hal itu maka perlu dilakukan 
fermentasi, keuntungan dari pengolahan ini yaitu untuk meningkatkan daya cerna juga sekaligus meningkatkan kadar protein dan dapat menghilangkan alfatoksin.

Pakan dalam bentuk pelet memiliki beberapa kelebihan yaitu dapat meningkatkan selera makan/palatabilitas, pemborosan ransum akibat tumpah/terbuang dapat ditekan, dapat mengefisiensikan formula ransum karena setiap butiran pelet mengandung nutrisi yang sama, ternak tidak diberi kesempatan untuk dapat memilih-milih makanan yang disukai.

Kelinci berbeda dengan ternak monogastrik lain dan termasuk pseudoruminant dengan digester mikrobial sekum seperti kuda sehingga tingkat toleransi terhadap pakan berserat diatas $12 \%$ dan protein rendah sebesar $12-15 \%$ relatif sama dengan standar protein pakan ruminansia. Dari keterangan tersebut dapat dinyatakan bahwa kulit daging buah kopi dapat dijadikan pakan ternak monogastrik karena mampu mencerna serat kasar yang tinggi, dan hal itulah yang melatarbelakangi penulis untuk melakukan penelitian tentang memanfaatkan kulit daging buah kopi fermentasi menggunakan (mikroorganisme lokal) MOL sebagai bahan pakan campuran yang dijadikan dalam bentuk ransum pelet yang diberikan pada kelinci rex jantan lepas sapih untuk melihat performansnya. Berdasarkan hasil analisis laboratorium Loka Penelitian Kambing Potong Sei Putih (2014) kulit daging buah kopi fermentasi memiliki kandungan nutrisi serat kasar (26,24\%), lemak kasar (2,31\%) dan protein kasar $(18,19 \%)$ sedangkan tanpa fermentasi memiliki serat kasar $(26,59 \%)$, lemak kasar $(2,33 \%)$ dan protein kasar (16,06\%).

\section{BAHAN DAN METODE PENELITIAN}

\section{Lokasi dan Waktu Penelitian}

Penelitian ini dilaksanakan di Laboratorium Biologi Ternak J1. Ahmad Sofyan Fakultas Pertanian Universitas Sumatera Utara. Penelitian ini akan dilaksanakan selama 10 minggu, termasuk masa adaptasi selama 2 minggu.

\section{Bahan dan Alat}

Kelinci peranakan Rex jantan lepas sapih sebanyak 20 ekor dengan bobot $913,5 \pm 60,49 \mathrm{~g}$, pelet perlakuan terdiri atas kulit daging buah kopi tanpa fermentasi, kulit daging buah kopi fermentasi, tepung jagung, bungkil kedelai, bungkil kelapa, dedak, ultra mineral, minyak makan, molases, urea, air minum, tepung daun wortel, obat-obatan dan vitamin seperti wormectin, antibloat, rodalon sebagai desinfektan kandang.

Kandang individu dengan ukuran 50 x 50 x $50 \mathrm{~cm}$ sebanyak 20 petak, pencetak pelet, timbangan kapasitas $10 \mathrm{~kg}$ dengan kepekaan $1 \mathrm{~g}$, tempat pakan dan tempat minum pada 
tiap kandang dengan total sebanyak 20 unit, mesin giling untuk membuat tepung, lampu 20 watt sebagai penerangan kandang, termometer untuk mengetahui suhu kandang, sapu lidi, sebagai alat pembersih kandang, telenan dan plastik transparan, terpal plastik sebagai alas untuk menyusun pelet, kardus sebagai tempat penyimpanan bahan untuk pelet.

\section{Metode Penelitian}

\section{Rancangan Penelitian}

Metode penelitian yang digunakan adalah rancangan acak lengkap (RAL) yang terdiri dari 4 perlakuan dan 5 ulangan sehingga diperoleh 20 unit percobaan.

Adapun perlakuan yang diteliti adalah sebagai berikut:

P0 : Pelet dengan pakan basal + kulit daging buah kopi tanpa fermentasi $30 \%$

P1 : Pelet dengan pakan basal + kulit daging buah kopi tanpa fermentasi $20 \%$ dan kulit daging buah kopi fermentasi $10 \%$

P2 : Pelet dengan pakan basal + kulit daging buah kopi tanpa fermentasi 10\% dan kulit daging buah kopi fermentasi $20 \%$

P3 : Pelet dengan pakan basal + kulit daging buah kopi fermentasi $30 \%$

Tabel 1. Formula Ransum Kelinci dengan kulit daging buah kopi (KDBK)

\begin{tabular}{|c|c|c|c|c|c|}
\hline \multirow[t]{2}{*}{ No } & \multirow[t]{2}{*}{ Bahan Pakan } & \multicolumn{4}{|c|}{ Perlakuan } \\
\hline & & $\mathrm{P} 0$ & $\mathrm{P} 1$ & $\mathrm{P} 2$ & P3 \\
\hline 1 & $\begin{array}{l}\text { KDBK non } \\
\text { Fermentasi }\end{array}$ & 30,00 & 20,00 & 10,00 & 0,00 \\
\hline 2 & KDBK Fermrntasi & 0,00 & 10,00 & 20,00 & 30,00 \\
\hline 3 & Tepung Jagung & 30,00 & 30,00 & 30,00 & 30,00 \\
\hline 4 & Dedak padi & 5,00 & 5,00 & 5,00 & 5,00 \\
\hline \multirow[t]{2}{*}{5} & Tepung Daun & & & & \\
\hline & Wortel & 15,00 & 15,00 & 15,00 & 15,00 \\
\hline 6 & Bungkil Kedelai & 11,00 & 11,00 & 11,00 & 11,00 \\
\hline 7 & Bungkil Kelapa & 3,60 & 3,60 & 3,60 & 3,60 \\
\hline 8 & Ultra Mineral & 0,50 & 0,50 & 0,50 & 0,50 \\
\hline 9 & Minyak Makan & 0,75 & 0,75 & 0,75 & 0,75 \\
\hline 10 & Molases & 3,00 & 3,00 & 3,00 & 3,00 \\
\hline 11 & Lysine & 0,50 & 0,50 & 0,50 & 0,50 \\
\hline & Metionin & 0,50 & 0,50 & 0,50 & 0,50 \\
\hline & Urea & 0,15 & 0,15 & 0,15 & 0,15 \\
\hline \multicolumn{2}{|c|}{ Total } & 100,00 & 100,00 & 100,00 & 100,00 \\
\hline \multicolumn{6}{|c|}{ Kandungan Nutrisi } \\
\hline 1 & $\begin{array}{l}\text { Energi metabilis/EM } \\
(\mathrm{kkal} / \mathrm{mg})\end{array}$ & $2.478,82$ & $2.549,53$ & $2.620,24$ & $2.691,54$ \\
\hline 2 & Protein kasar/PK (\%) & 15,00 & 15,21 & 15,43 & 15,64 \\
\hline 3 & Serat kasar/SK (\%) & 11,94 & 11,91 & 11,87 & 11,84 \\
\hline & & & 217 & & \\
\hline
\end{tabular}




\begin{tabular}{llcccc}
4 & Lemak kasar/LK (\%) & 2,55 & 2,56 & 2,56 & 2,56 \\
5 & Harga pemakaian (Rp) & 3188,15 & 3201,55 & 3214,95 & 3228,35 \\
\hline
\end{tabular}

Model Matematik RAL adalah sebagai berikut

$$
Y_{i j}=\mu+\sigma_{i}+\varepsilon_{i j}
$$

Keterangan :

$$
\begin{aligned}
\text { Yij } & =\text { nilai pengamatan pada perlakuan ke-i ulangan ke } \mathrm{j} \\
\mathrm{i} & =1,2,3,4,5 \text { (ulangan) } \\
\mathrm{j} & =1,2,3,4 \text { (perlakuan) } \\
\mu & =\text { nilai tengah umum } \\
\sigma_{\mathrm{i}} & =\text { pengaruh perlakuan ke-i } \\
\varepsilon_{\mathrm{ij}} & =\text { efek galat percobaan pada perlakuan ke-i, ulangan ke-j }
\end{aligned}
$$

\section{Parameter Penelitian}

1. Konsumsi Ransum

Konsumsi ransum dihitung dengan cara menimbang jumlah pakan yang diberikan dikurangi dengan sisa pakan selama penelitian yang dinyatakan dalam g/ekor/hari dalam bentuk bahan kering (BK)

Konsumsi $=$ Pakan yang diberikan - pakan sisa $(\mathrm{g} / \mathrm{ekor} / \mathrm{hari})$

2. Pertambahan Bobot Badan

Pertambahan bobot badan harian merupakan selisih antara bobot badan awal dengan bobot badan akhir dibagi dengan lama pemeliharaan dinyatakan dalam gram/ekor/minggu.

PBBH = bobot akhir - bobot awal

$$
\text { Lama pemeliharaan }
$$

3. Konversi ransum

Konversi pakan Merupakan perbandingan antara jumlah konsumsi pakan dengan pertambahan bobot badan selama pemeliharaan dinyatakan dalam gram/ekor/hari

Konversi pakan $=\underline{\text { Konsumsi pakan }}$

$\mathrm{PBBH}$

Pengolahan Kulit Daging Buah Kopi Fermentasi Dengan Rhizopus sp, Saccharomyces sp dan Lactobacillus sp.

1. Pembuatan Inokulen Cair 
Tahap pertama dalam pengolahan kulit daging buah kopi fermentasi yaitu dengan pembuatan inokulan cair sebagai fermentornya. Cara pembuatannya yaitu dengan menyediakan air dalam galon sebanyak 10 liter, kemudian campurkan air gula sebanyak 1,5 liter, kemudian tambahkan bakteri fermentor yaitu Rhizopus sp. (ragi tempe), Saccaromyces sp. (ragi tape) masing-masing sebanyak $60 \mathrm{~g}$ dan Lactobacillus sp. (yoghurt) sebanyak $15 \mathrm{ml}$. Tutup dengan plastik dan diamkan selama 3 hari. Keberhasilan inokulan cair yang dibuat yaitu dengan adanya bau sedikit asam dan harum. 10 liter inokulen cair dapat memfermentasi $\pm 300 \mathrm{~kg}$ bahan pakan (Compose Center, 2009).

\section{Pembuatan Fermentasi Kulit Daging Buah Kopi}

Tahap selanjutnya setelah inokulan cair tersebut jadi, kemudian siapkan kulit daging buah kopi yang akan difermentasi di dalam bak fermentasi setelah diangin-anginkan hingga mencapai kebasahan $60 \%$. Campurkan inokulen cair tersebut dengan kulit daging buah kopi dan tambahkan dedak padi sebanyak 15\% dari bobot kulit daging buah kopi yang akan difermentasi. Tutup dengan terpal atau dengan penutup yang terbuat dari sabut kelapa selama 5 hari dan dibolak-balik. Ukur suhunya setiap hari hingga suhu mencapa $40^{\circ} \mathrm{C}$, kemudian jemur dengan dikering anginkan dan selanjutnya digiling hingga halus (Compose Center, 2009).

\section{HASIL DAN PEMBAHASAN}

Hasil penelitian tentang pemanfaatan kulit daging buah kopi fermentasi mikroorganisme lokal (MOL) sebagai ransum dalam bentuk pelet terhadap peformans kelinci peranakan rex jantan lepas sapih dapat dilihat pada tabel 2.

Tabel 2 . Tabel rekapitulasi data peformans kelinci peranakan rex lepas sapih selama penelitian

\begin{tabular}{cccc}
\hline \multirow{2}{*}{ Perlakuan } & \multicolumn{3}{c}{ Rataan Parameter } \\
\cline { 2 - 4 } & $\begin{array}{c}\text { Konsumsi Pakan } \\
\text { (g/ekor/hari) }\end{array}$ & PBB (g/ekor/hari) & Konversi Pakan \\
\hline P0 & $81,59^{\text {tn }}$ & $38,25^{\text {tn }}$ & $2,13^{\text {tn }}$ \\
P1 & $78,86^{\text {tn }}$ & $38,10^{\text {tn }}$ & $2,07^{\text {tn }}$ \\
P2 & $82,70^{\text {tn }}$ & $39,61^{\text {tn }}$ & $2,09^{\text {tn }}$ \\
P3 & $84,23^{\text {tn }}$ & $40,75^{\text {tn }}$ & $2,07^{\text {tn }}$ \\
\hline
\end{tabular}

Keterangan: $\mathrm{tn}=$ tidak nyata

\section{Konsumsi Ransum}

Tabel 2 terlihat bahwa rataan total konsumsi ransum dalam bahan kering adalah sebesar 81,85 g/ekor/hari. Rataan konsumsi tertinggi yaitu pada P3 sebesar 84,23 g/ekor/hari dan rataan konsumsi terendah adalah P1 yaitu 78,86 g/ekor/hari. Dari data yang diperoleh 
menunjukkan bahwa konsumsi ytang dihasilkan menunjukan tingkat yang lebih baik dibandingkan dengan penelitian sebelumnya yang memanfaatkan limbah pertanian yang difermentasi menggunakan bioaktifator yang sama terhadap objek penelitian yang sama pula yaitu kelinci rex lepas sapih. Hal ini dibuktikan dengan pernyataan berikut menurut hasil penelitian Tarigan (2013) yang menggunakan bioaktifator berupa (mikroorganisme lokal) MOL terhadap pakan yang diberikan kepada objek yang sama yaitu kelinci peranakan rex lepas sapih menunjukan bahwa total rataan konsumsinya mencapai 78,88 g/hari. Menurut hasil penelitian Magdalena (2013) yang menggunakan objek kelinci dan bioaktifator yang sama menunjukkan bahwa total rataan konsumsi yang dihasilkan mencapai 48,17 g/hari atau rataan konsumsi tertinggi mencapai 49,51 g/ekor/hari.

Berdasarkan analisis ragam menunjukan bahwa pengaruh pemberian kulit daging buah kopi yang dicampur dengan pakan basal dalam bentuk pelet tidak berpengaruh nyata terhadap konsumsi. Dalam hal ini menunjukan bahwa kulit daging buah kopi fermentasi mempunyai kualitas dan palatabilitas yang relatif sama dengan kulit daging buah kopi tanpa fermentasi. Tingkat perbedaan konsumsi dipengaruhi oleh beberapa faktor ternak antara lain umur, palatabilitas ransum, aktivitas ternak, bau, rasa, tekstur, energi ransum dan tingkat protein (Manik, 2000). Konsumsi ransum dipengaruhi oleh kesehatan ternak, palatabilitas, mutu ransum dan tata cara pemberian (Anggorodi, 1990). Perbedaan konsumsi ransum dipengaruhi oleh beberapa faktor, antara lain, bobot badan, umur, dan kondisi tubuh yaitu normal atau sakit, stres yang diakibatkan oleh lingkungan, genetik dan tingkat kecernaan ransum (Parakkasi, 1983).

\section{Pertambahan Bobot Badan}

Tabel 2 terlihat bahwa rataan total pertambahan bobot badan kelinci adalah sebesar 39,18 g/ekor/hari. Dengan rataan pertambahan bobot badan tertinggi pada P3 sebesar 40,75 g/ekor/hari dan pertambahan bobot badan terendah pada P1 yaitu sebesar 38,10 g/ekor/hari.

Analisis ragam menunjukan hasil yang tidak berbeda nyata. Hal ini menunjukan bahwa pemanfaatan kulit daging buah kopi fermentasi sebagai bahan campuran dalam pembuatan ransum dalam bentuk pelet tidak berbeda nyata terhadap pertambahan bobot badan kelinci peranakan rex jantan lepas sapih.

Perbedaan pertambahan bobot badan dipengaruhi oleh lingkungan dan suhu. Hal ini sesuai dengan pernyataan Wahyu (1992) yang menyatakan bahwa faktor-faktor yang mempengaruhi pertumbuhan adalah bangsa, jenis kelamin, energi, metabolisme kandungan protein dan suhu lingkungan. Total pertambahan bobot badan harian pada penelitian ini yaitu 
sebesar 39,18 g/ekor/hari. Magdalena (2013) menyatakan dalam hasil penelitiannya bahwa pertambahan bobot badan yang dihasilkan kelinci rex lepas sapih yang diberikan pakan fermentasi menggunakan MOL dalam bentuk pelet mencapai bobot dengan rataan tertinggi yaitu 21,17 g/ekor/hari dengan total rataan yaitu 19,86 g/hari.

Menurut Tarigan (2013) dalam hasil penelitiannya menyatakan bahwa kelinci rex lepas sapih yang diberikan pakan fermentasi menggunakan bioaktifator yang sama dalam bentuk pelet menunjukan pertambahan bobot badan tertinggi yaitu 14,88 g/ekor/hari atau dengan total rataan mencapai 11,73 g/ekor. Hal ini menunjukan bahwa pertambahan bobot badan harian selama penelitian sesuai dengan yang diharapkan, karena pertambahan bobot badan kelinci yang diperoleh lebih tinggi dibandingkan dengan penelitian sebelumnyayang menggunakan MOL sebagai fermentor pakannya, karena bila ditinjau dari kandungan nutrisinya protein kasar pada kulit daging buah kopi fermentasi lebih tinggi yaitu sebesar $18,19 \%$ dan serat kasarnya sebesar 26,24\% sementara pada penelitian sebelumnya yang menggunakan pod kakao fermentasi MOL, protein kasarnya hanya sebesar $12,38 \%$ dan serat kasarnya yaitu $30,19 \%$.

Salah satu faktor yang memberikan pengaruh tidak berbeda nyata pada pertambahan bobot badan pada penelitian ini adalah konsumsi pakan yang tidak berbeda nyata. Hal ini disebabkan bahwa kulit daging buah kopi fermentasi dan tanpa fermentasi sama-sama disukai oleh kelinci dan palatabilitas yang hampir sama. Besar kecilnya konsumsi pakan tergantung pada palatabilitas, kandungan bahan kering pakan, ukuran tubuh ternak, jenis pakan dan keadaan ternak.

\section{Konversi Ransum}

Tabel 2 dapat dilihat bahwa rataan konversi ransum kelinci terendah adalah perlakuan P3 sebesar 2,07 dan yang tertinggi yaitu pada perlakuan P0 sebesar 2,13 dengan total rataan konversi semua perlakuan yaitu sebesar 2,09. Konversi ransum memberikan penilaian terhadap efisiensi penggunaan ransum oleh kelinci dengan adanya pertambahan bobot badan yang lebih baik bila dibandingkan dengan penelitian sebelumnya yang menggunakan bioaktifator yang sama yaitu MOL sebagai fermentor bahan pakan yang diujikan pada objek penelitian yang sama. Hasil penelitian Tarigan (2013), menunjukan total rataan konversi yang diperoleh yaitu sebesar 6,74 dengan nilai konversi terendah yaitu 5,77 dan menurut hasil penelitian Magdalena (2013) total nilai rataan konversi yang diperoleh yaitu sebesar 5,66 dengan nilai rataan konversi terendah yaitu 5,55. 
Hasil analisis ragam menunjukan bahwa konversi pakan kelinci rex jantan lepas sapih yang diperoleh selama penelitian menunjukan hasil yang tidak berbeda nyata tetapi pakan yang difermentasi dapat berpengaruh menurunkan angka konversinya. Hal ini menunjukan bahwa kulit daging buah kopi fermentasi sebagai bahan campuran dalam bentuk pelet dapat menurunkan konversi ransum tersebut karena efisiensi penggunaan pakannya yang tinggi dan baik. Hal ini sesuai dengan pernyataan Usman dan Susilowati (2006) yang menyatakan konversi pakan kelinci yang diberikan pakan fermentasi lebih rendah dari konversi pakan kelinci yang tidak diberikan pakan tanpa fermentasi.

Jika nilai konversi pakan yang ditunjukkan rendah, maka efisiensi penggunaan pakan tinggi atau baik. Pakan yang berkualitas akan digunakan seefisien mungkin oleh ternak menjadi produksi atau pertumbuhan maksimal, sehingga konversinya rendah. Pemberian pakan bentuk pelet dapat meningkatkan performa dan konversi pakan ternak bila dibandingkan dengan pakan bentuk mash. Semakin baik mutu ransum, semakin kecil pula konversi pakannya, angka konversi ransum menunjukkan tingkat efisiensi penggunaan ransum.

\section{KESIMPULAN}

Penggunaan kulit daging buah kopi yang difermentasi menggunakan MOL (mikroorganisme lokal) yang terdiri dari Rhizopus sp, Saccaromyces sp, dan Lactobacillus sp dapat digunakan sebagai campuran bahan pakan dalam bentuk pelet ransum yang diberikan kepada kelinci peranakan rex lepas sapih sampai pada level $30 \%$.

\section{DAFTAR PUSTAKA}

Anggorodi, R. 1990. Ilmu Makanan Ternak Umum. Gramedia, Jakarta.

Compost Center. 2009. Guidelines Training on Compost: A Takakura Method USU Press. Medan.

Dinas Pertanian Bidang Perkebunan Kabupaten Karo. 2008. Disitasi Skripsi Arta. H. S. 2009. Analisa Usaha Tani Kopi di Kecamatan Simpang Empat Kabupaten Karo. USU-Press. Medan.

Laboratorium Nutrisi Loka Penelitian Kambing Potong Sei Putih. 2014. Sumatera Utara.

Magdalena. 2013. Subtitusi Dedak Padi Dengan Daging Buah Kakao Fermentasi Dalam Ransum Pellet Terhadap Peformans Kelinci Rex Jantan Lepas Sapih. USU-Pers. Medan. 
Manik, J. H. 2000. Pengaruh Pemberian Enzim Siniesis Terhadap gala tumbuh Babi Fase Starter. Disitasi Skripsi Fakultas Peternakan Universitas HKBP Nomensen. Medan.

Parakkasi, A. 1983. Ilmu Nutrisi dan Makanan Ternak Ruminansia. UI Press. Jakarta.

Tarigan, L. D. 2013. Pemanfaatan Kulit Pisang Raja Difermentasi MOL dan Trichoderma harzianum Pada Berbagai Ransum Terhadap Peformans Kelinci Rex Jantan Lepas Sapih. USU-Press. Medan.

Usman, A dan Susilowati, S. 2006. Uji kecernaan bahan kering dan konversi pakan complete feed yang menggunakan campuran onggok dan isi rumen sapi pada penggemukan kambing peranakan etawah. Jurnal Ilmiah Dinamika Rekasatwa. Vol 2(1) : 12 - 25.

Wahyu, J. 1992. Ilmu Nutrisi Ternak. Gadjah Mada University Press. Yogyakarta. 